\title{
Corrosion of Stainless Steels in NaCl-KCl Based Melts
}

\author{
I.B. Polovov ${ }^{a}$, A.V. Abramov ${ }^{a}$, O.I. Rebrin ${ }^{a}$, V.A. Volkovich ${ }^{a}$, E.I. Denisov ${ }^{b}$, \\ T.R. Griffiths ${ }^{\mathrm{c}}$, I. May ${ }^{\mathrm{d}}$, and H. Kinoshita ${ }^{\mathrm{d}}$ \\ a Department of Rare Metals and Nanomaterials, Ural Federal University, Ekaterinburg, \\ 620002, Russia \\ ${ }^{\mathrm{b}}$ Department of Radiochemistry, Ural Federal University, Ekaterinburg, \\ 620002, Russia \\ ${ }^{\mathrm{c}}$ Redston Trevor Consulting, Ltd., Leeds, LS17 8RF, UK \\ ${ }^{\mathrm{d}}$ The Centre for Radiochemistry Research, The University of Manchester, Manchester, \\ M13 9PL, UK
}

\begin{abstract}
Corrosion behavior of stainless steel types AISI 316L, 316Ti and 321 was studied at $750{ }^{\circ} \mathrm{C}$ in $\mathrm{NaCl}-\mathrm{KCl}$ equimolar melts. Iron, chromium and manganese species constitute the major corrosion products. The following mechanism of stainless steel corrosion in molten chlorides was proposed: 1) chemical interaction between the alloy and the salt intensified by the formation of microgalvanic pairs; 2) formation of chromium and molybdenum carbidecontaining phases in steel as a result of heating to $750{ }^{\circ} \mathrm{C} ; 3$ ) additional formation of galvanic pairs between the grains of austenitic alloys and the carbide phases at the grain boundaries resulting in enhanced intergranular corrosion.
\end{abstract}

\section{Introduction}

Alkali halide based molten electrolytes have a wide range of potential applications for electrowinning and electrorefining of metals and also for pyrochemical reprocessing of spent nuclear fuels. However, the industrial scale use of fused salts is limited by the problem of finding suitable corrosion resistant materials stable in contact with molten salt media. Corrosion of metals in molten salts was studied for a number of years (1-21), but the corrosion mechanism and the effect of melt properties upon it were not studied in detail, especially for corrosion of alloys in chloride melts under an inert atmosphere.

In the present work the corrosion behavior of stainless steel types AISI 316L, 316 Ti and 321 was studied at $750{ }^{\circ} \mathrm{C}$ in $\mathrm{NaCl}-\mathrm{KCl}$ equimolar mixture based melts by gravimetric method. In addition the surface of the corroded samples was analyzed using metallographic and X-ray microanalysis.

\section{Experimental}

The $\mathrm{NaCl}-\mathrm{KCl}$ equimolar mixture was prepared from the individual $\mathrm{NaCl}$ and $\mathrm{KCl}$ reagent grade salts that were dried for three hours at $250{ }^{\circ} \mathrm{C}$, then melted and sparged with a mixture of chlorine and hydrogen chloride for four hours, and finally kept under vacuum for further 3 hours. For the preparation of $\mathrm{NaCl}-\mathrm{KCl}$ melt the individual salts were fused in a required proportion and held for 2-3 hours under purified argon. 
Austenite chromium-nickel stainless steels AISI 321, AISI 316Ti and AISI 316L (Table I) were chosen for this study because they have increased stability against intergranular corrosion. AISI32 1 type steel is characterized by high heat resistance up to $750-850{ }^{\circ} \mathrm{C}$. AISI 316 steels are differing from other steels by enhanced corrosion resistance especially against pitting corrosion. AISI $316 \mathrm{Ti}$ is stabilized by titanium, and therefore it has sensitization resistance (prevention of precipitation of chromium carbides at the grain boundaries) in the temperature range from 550 to $800{ }^{\circ} \mathrm{C}$. AISI $316 \mathrm{~L}$ is a low carbon steel and thus also reduces the sensitization effect caused by the high temperatures.

TABLE I. Chemical composition of studied stainless steels (22).

\begin{tabular}{ccccccccccc}
\hline $\begin{array}{c}\text { Type of } \\
\text { steel }\end{array}$ & $\mathbf{C}$ & $\mathbf{~ S i}$ & $\mathbf{M n}$ & $\mathbf{C r}$ & $\mathbf{N i}$ & $\mathbf{T i}$ & $\mathbf{M o}$ & $\mathbf{S}$ & $\mathbf{P}$ & $\mathbf{C u}$ \\
\hline AISI 316L & $<0.03$ & $<0.4$ & $1.0-2.0$ & $16.8-18.3$ & $13.5-15.0$ & - & $2.2-2.8$ & 0.02 & 0.03 & - \\
AISI 3 16Ti & $<0.1$ & $<0.8$ & $<2.0$ & $16.0-18.0$ & $12.0-14.0$ & $0.5-0.7$ & $2.0-3.0$ & 0.02 & 0.035 & 0.3 \\
AISI 321 & $<0.12$ & $<0.8$ & $<2.0$ & $17.0-19.0$ & $9.0-11.0$ & $0.5-0.8$ & - & 0.02 & 0.035 & 0.3 \\
\hline
\end{tabular}

Before the experiments samples of AISI 321, AISI 316Ti and AISI 316L types of steel were prepared. Steel bars were cut to produce cylindrical billets 5-7 $\mathrm{mm}$ length. Each billet was polished to a mirror shine, washed by water and then by acetone. The prepared samples were dried, then weighted and their surface area was measured.

The corrosion experiments were conducted in silica cells closed by vacuum rubber stoppers. The alumina crucible was used to contain the melt and steel samples. The melt in the cell was kept under excessive pressure of purified argon to prevent possible oxygen contamination from the surrounding atmosphere. All the experiments were conducted in $\mathrm{NaCl}-\mathrm{KCl}$ equimolar mixture at $750{ }^{\circ} \mathrm{C}$. Duration of the corrosion tests was varied from 1 to $30 \mathrm{~h}$ and several cylindrical samples of each type of steel were used in each experiment. After conducting the experiments the weight decrease of the samples was determined and averaged.

Quenched melt samples taken after each experiment were analyzed to determine the content of the elements of interest using ICP MS method (Elan 9000, Perkin Elmer) and X-ray fluorescence spectroscopy (ARL QUANT'X). The surface of steel samples after corrosion tests was examined using metallographic analysis (Olympus GX-71F) and Xray microanalysis (JSM 6490).

\section{Results and discussion}

The results of measuring the average weight decrease and the corrosion rate of different steel samples in $\mathrm{NaCl}-\mathrm{KCl}$ melt are shown on Figure 1 and 2. The rate of the corrosion increased during the initial period of the exposure before reaching a maximum value. Then the rate of the weight loss began to decrease and approached a constant value at $c a .0 .02 \mathrm{mg} /\left(\mathrm{cm}^{2} \cdot \mathrm{h}\right)$ for AISI $316 \mathrm{Ti}$ and $316 \mathrm{~L}$, and $c a .0 .04 \mathrm{mg} /\left(\mathrm{cm}^{2} \cdot \mathrm{h}\right)$ for AISI 321. These results indicate a relatively low corrosion rate. According to the metallographic analysis the mechanism of the corrosion is similar for all types of steel studied here. During the initial period there is gradual etching of the sample surface (Figure 3, a, c, e). After $30 \mathrm{~h}$ of exposure a weak intergranular corrosion was noticed (Figure $3, \mathrm{~b}, \mathrm{~d}, \mathrm{f}$ ). In terms of intensity and thickness of the layer of intergranular 
corrosion the studied steels can be ranged in the order AISI $321>$ AISI $316 \mathrm{Ti}>$ AISI 316L. This sequence correlates well with the carbon content in the steels (Table I).

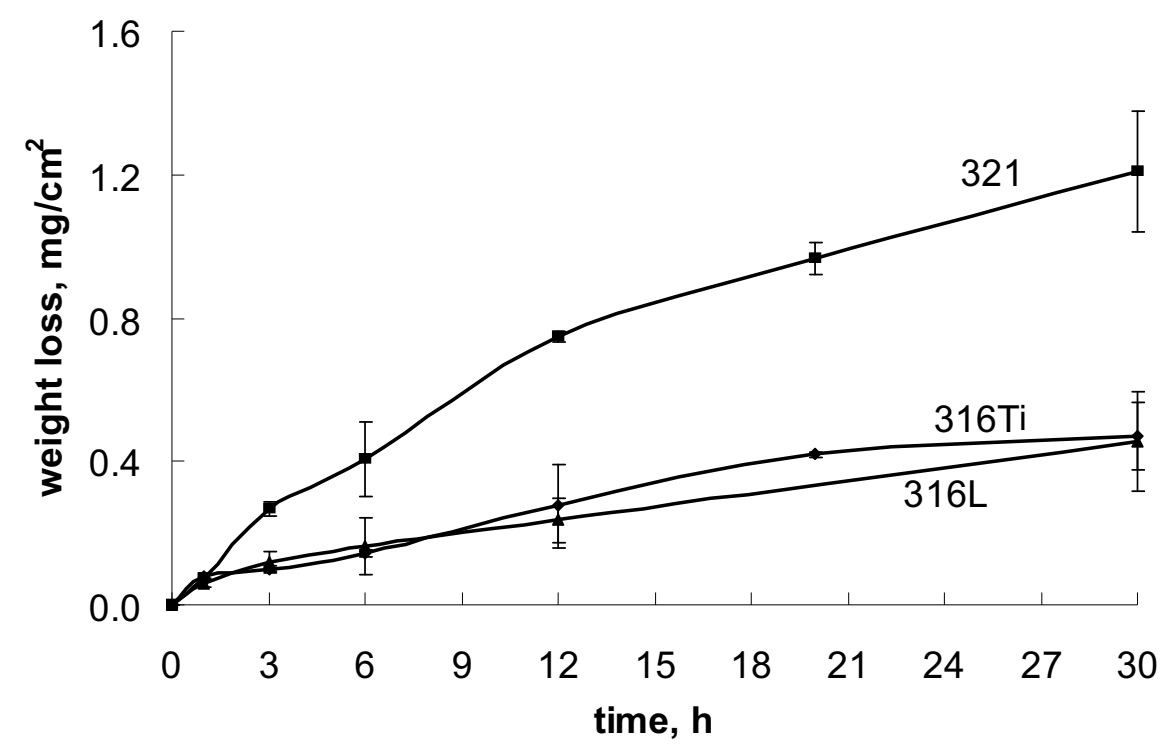

Figure 1. The decrease of mass of stainless steel samples (types AISI 321, 316L and 316Ti) exposed to $\mathrm{NaCl}-\mathrm{KCl}$ melt, $750{ }^{\circ} \mathrm{C}$.

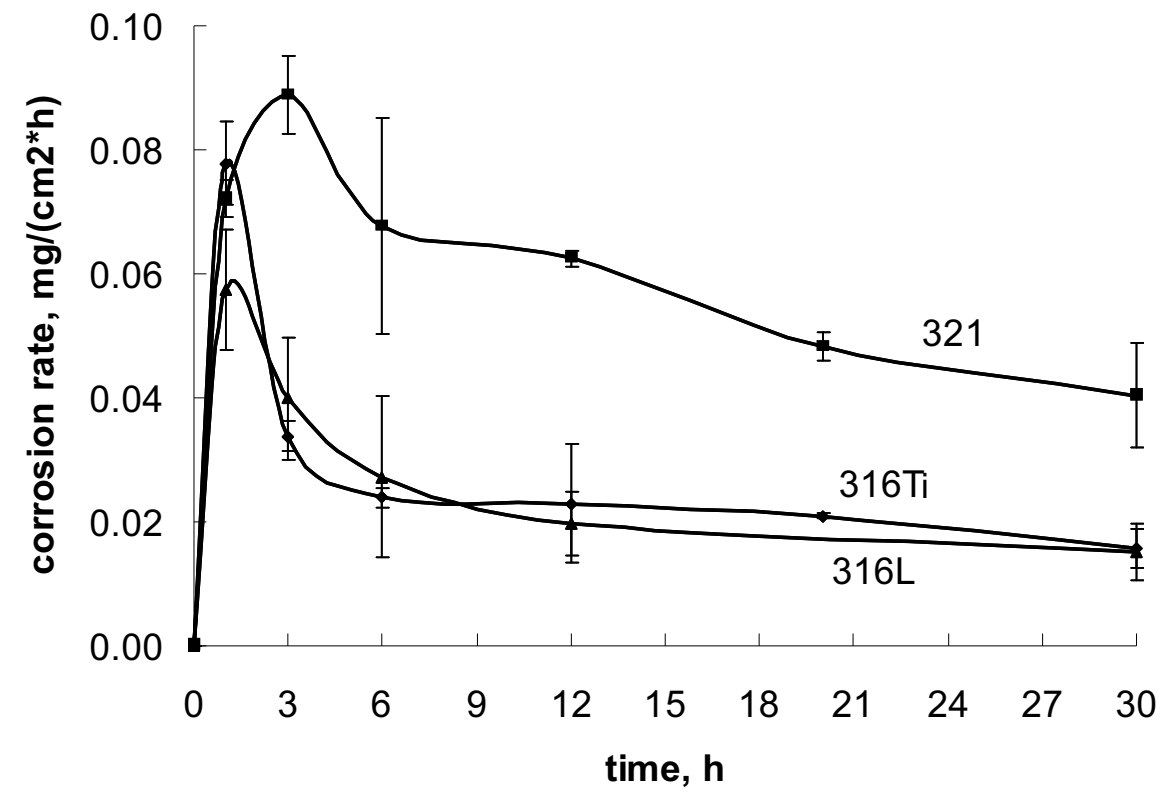

Figure 2. The corrosion rates of stainless steel types AISI 321, 316L and 316Ti exposed to $\mathrm{NaCl}-\mathrm{KCl}$ melt, $750{ }^{\circ} \mathrm{C}$.

Analysis of the quenched electrolyte samples (Table II-IV) showed that iron, chromium and manganese species were the major corrosion products dissolved in the molten salt. These results were also confirmed by X-Ray microanalysis of the corroded samples, the surface of steel samples was depleted in manganese and chromium and 
enriched in nickel and molybdenum (Figure 4). The iron content in the melt gradually increases with time, whereas chromium concentration rises sharply after $6 \mathrm{~h}$ exposure for AISI 321 and 316Ti and after $20 \mathrm{~h}$ for AISI 316L alloy. Manganese content in the molten electrolyte remains almost constant in entire time interval.
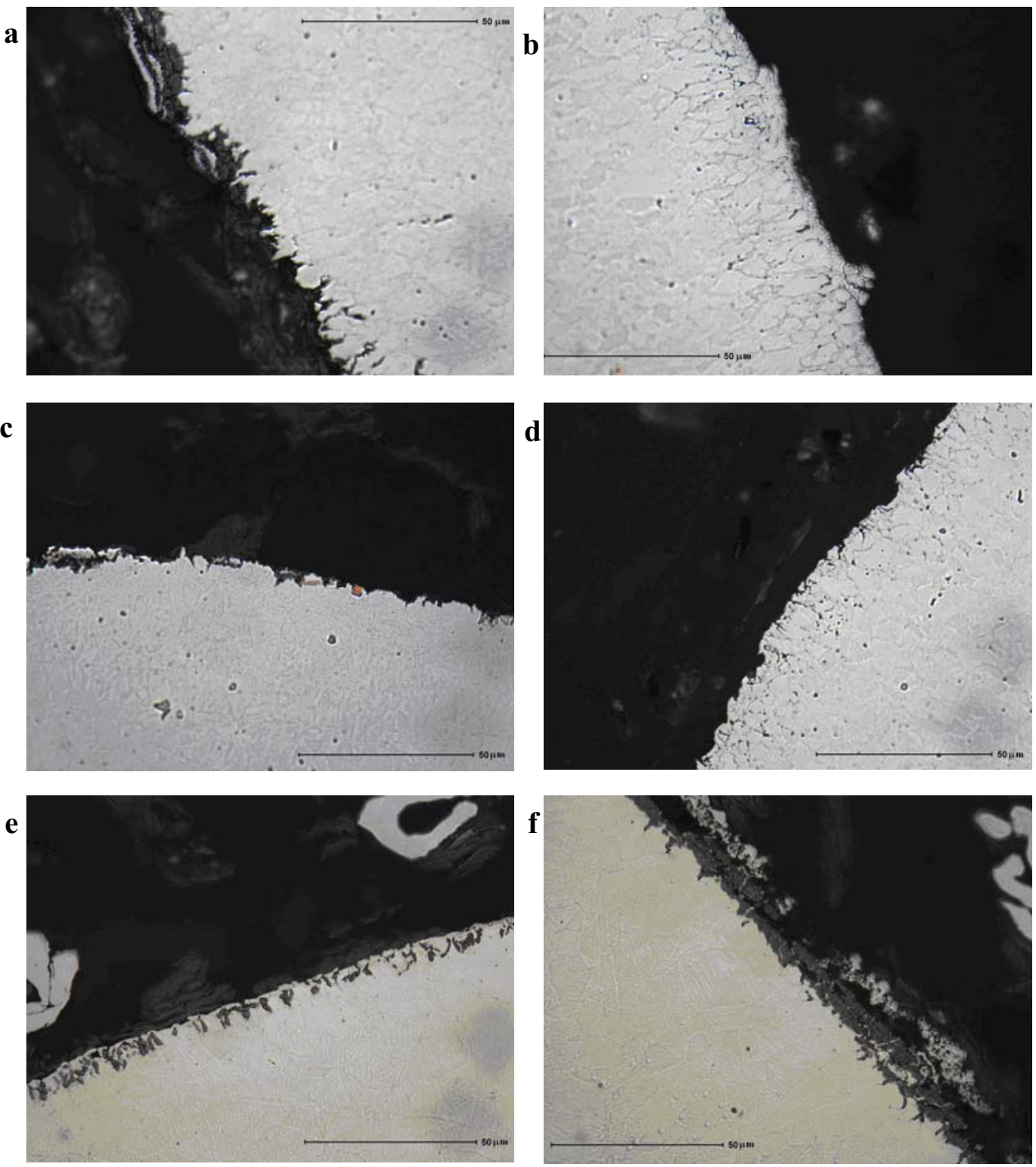

Figure 3. Microstructure of AISI $321(\mathrm{a}, \mathrm{b}), 316 \mathrm{Ti}(\mathrm{c}, \mathrm{d})$ and $316 \mathrm{~L}(\mathrm{e}, \mathrm{f})$ steel sample after $6 \mathrm{~h} \mathrm{(a,c,e)}$ and $30 \mathrm{~h} \mathrm{(b,} \mathrm{d,} \mathrm{f)} \mathrm{contact} \mathrm{with} \mathrm{NaCl-KCl} \mathrm{melt} \mathrm{at} 750{ }^{\circ} \mathrm{C}$.

The following mechanism of stainless steel corrosion in molten chlorides can thus be proposed. At the first stage a chemical exchange reaction between the alloy and the salt occurs. As a result of this interaction gradual etching of samples is taking place. The rate of the corrosion in the initial moment of time is highest due to significant difference between the values of the red-ox potentials $\mathrm{E}_{\mathrm{Me}^{n+}} / \mathrm{Me}$ and $\mathrm{E}_{\mathrm{A}}{ }^{+} / \mathrm{A}$, where $\mathrm{Me}-$ component of 
steel, A - alkali metal ( $\mathrm{Na}$ or $\mathrm{K})$. As the potential of the steel in the melt approaches a certain stationary value, the corrosion rate decreases. At the first stage iron predominantly dissolves due to its higher content in the steel and strong interaction between the components in Fe-Cr-Ni alloys. The dissolution of other than iron elements by such mechanism is less possible except the most electronegative manganese and titanium (23). However, due to the formation of strong titanium carbides and carbonitrides, titanium does not corrode. Moreover, these carbon-containing grains can act as cathodes in respect to the alloy thus enhancing the corrosion process.

TABLE II. Metal content (ppm) in quenched NaCl-KCl based melts held in contact with AISI 321 steel samples at $750{ }^{\circ} \mathrm{C}$

\begin{tabular}{ccccc}
\hline Element & $\mathbf{3}$ & $\mathbf{6}$ & $\mathbf{E x p o s u r e ~ t i m e , ~} \mathbf{2 0}$ & $\mathbf{3 0}$ \\
\hline $\mathrm{Fe}$ & $315 \pm 114$ & $899 \pm 122$ & $1178 \pm 140$ & $1920 \pm 175$ \\
$\mathrm{Cr}$ & $375 \pm 115$ & $374 \pm 12$ & $628 \pm 175$ & $2940 \pm 184$ \\
$\mathrm{Mn}$ & $340 \pm 141$ & $889 \pm 149$ & $793 \pm 157$ & $636 \pm 219$ \\
$\mathrm{Mo}$ & $54 \pm 22$ & $95 \pm 18$ & $74 \pm 23$ & $76 \pm 24$ \\
$\mathrm{Ti}$ & not found & not found & not found & not found \\
$\mathrm{Ni}$ & not found & not found & not found & not found \\
\hline
\end{tabular}

TABLE III. Metal content (ppm) in quenched $\mathrm{NaCl}-\mathrm{KCl}$ based melts held in contact with AISI 316Ti steel samples at $750{ }^{\circ} \mathrm{C}$

\begin{tabular}{ccccc}
\hline \multirow{2}{*}{ Element } & $\mathbf{3}$ & $\mathbf{6}$ & $\begin{array}{c}\text { Exposure time, } \mathbf{h} \\
\mathbf{2 0}\end{array}$ & $\mathbf{3 0}$ \\
\hline $\mathrm{Fe}$ & $593 \pm 122$ & $942 \pm 131$ & $1222 \pm 131$ & $2016 \pm 175$ \\
$\mathrm{Cr}$ & not found & $11 \pm 12$ & $1099 \pm 228$ & $1238 \pm 193$ \\
$\mathrm{Mn}$ & $383 \pm 140$ & $444 \pm 140$ & $435 \pm 132$ & $706 \pm 184$ \\
$\mathrm{Mo}$ & $51 \pm 19$ & $130 \pm 18$ & $252 \pm 18$ & $401 \pm 27$ \\
$\mathrm{Ti}$ & not found & not found & not found & not found \\
$\mathrm{Ni}$ & not found & not found & not found & not found \\
\hline
\end{tabular}

TABLE IV. Metal content (ppm) in quenched NaCl-KCl based melts held in contact with AISI 316L steel samples at $750{ }^{\circ} \mathrm{C}$

\begin{tabular}{ccccc}
\hline Element & $\mathbf{3}$ & $\mathbf{6}$ & $\begin{array}{c}\text { Exposure time, } \mathbf{h} \\
\mathbf{2 0}\end{array}$ & $\mathbf{3 0}$ \\
\hline $\mathrm{Fe}$ & $671 \pm 137$ & $696 \pm 137$ & $970 \pm 149$ & $4836 \pm 298$ \\
$\mathrm{Cr}$ & not found & not found & not found & $746 \pm 199$ \\
$\mathrm{Mn}$ & $920 \pm 186$ & $472 \pm 162$ & $410 \pm 162$ & $1256 \pm 261$ \\
$\mathrm{Mo}$ & $137 \pm 50$ & $78 \pm 17$ & not found & $373 \pm 25$ \\
$\mathrm{Ti}$ & not found & not found & not found & not found \\
$\mathrm{Ni}$ & not found & not found & not found & not found \\
\hline
\end{tabular}

At the second stage, chromium-containing carbide phases are formed along the grain boundaries. The formation of chromium carbides is caused by heating (24-28) and for the steels working in contact with high temperature melts is unavoidable. The interstitial carbon atoms diffuse to the grain boundaries very rapidly and the subsequent carbide precipitation depletes the matrix and the grain boundary regions surrounding the carbide phases in chromium which diffuses much more slowly. As a result additional formation of galvanic pairs between the grains of austenitic alloys and the carbide phases at the grain boundaries occurs. As a result of the formed galvanic couple $\mathrm{Me}_{6} \mathrm{C}\left(\mathrm{Me}_{23} \mathrm{C}_{6}\right) \mathrm{NaCl}$ $\mathrm{KCl}$ |steel intergranular corrosion takes place. Increasing carbon content in the steel results in the increase of the sensitization (precipitation of chromium carbides at the grain boundaries). 


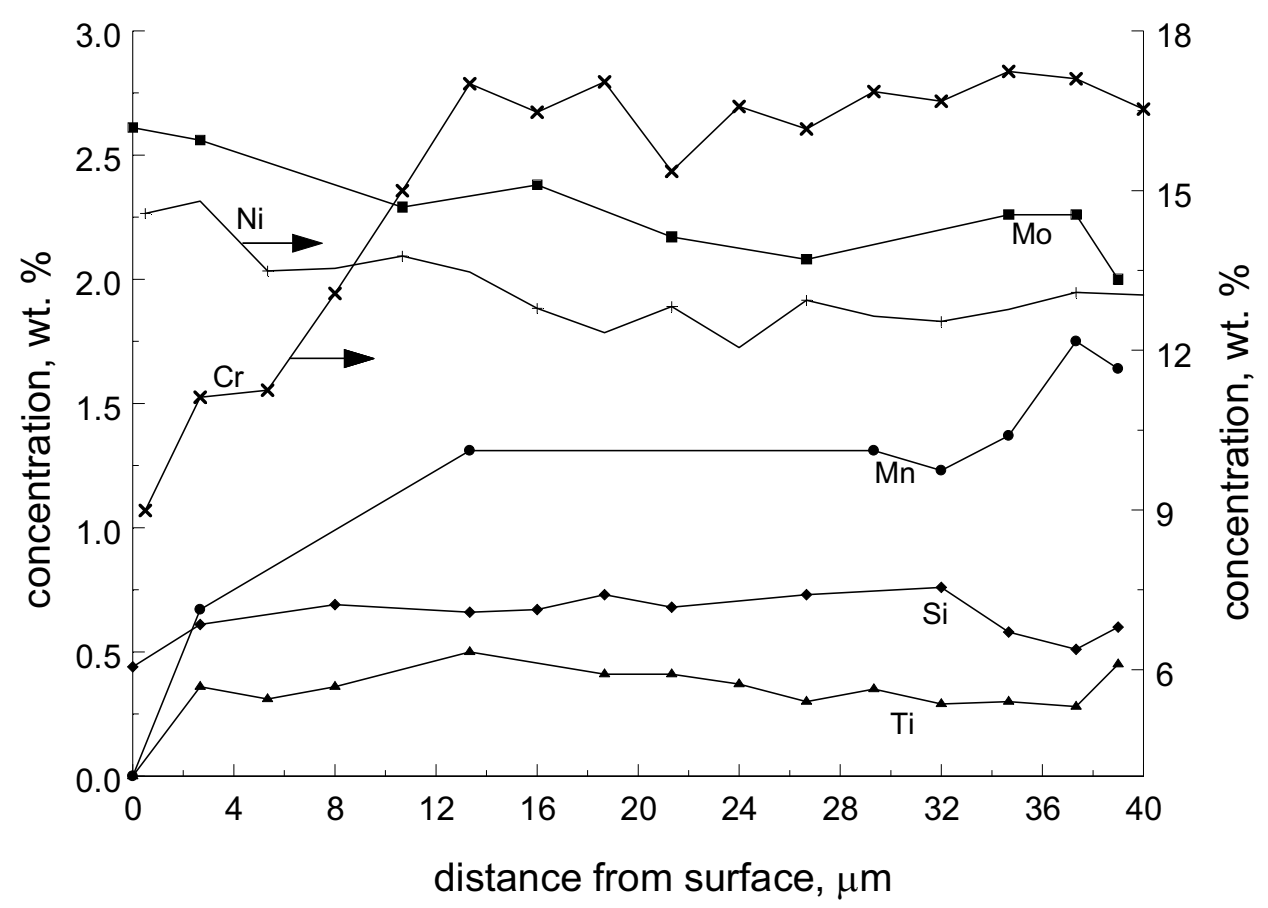

Figure 4. Distribution of elements in the surface layer of AISI 316Ti stainless steel samples after $30 \mathrm{~h}$ exposure to $\mathrm{NaCl}-\mathrm{KCl}$ melt at $750{ }^{\circ} \mathrm{C}$ (for $\mathrm{Ni}$ and $\mathrm{Cr}$ content use the right $\mathrm{Y}$-axis).

\section{Conclusions}

Corrosion behavior of the stainless steel types AISI 316L, 316Ti and 321 was investigated at $750{ }^{\circ} \mathrm{C}$ in the melts based on $\mathrm{NaCl}-\mathrm{KCl}$ equimolar mixture. It was found that iron, chromium and manganese species are the major corrosion products. It was shown that carbon content determines corrosion resistance of steels through the sensitization effect caused by the high temperatures. The mechanism of stainless steel corrosion is suggested.

\section{References}

1. C. Edelcanu, J. G. Gibson and J. E. Meredith, J. Iron and Steel, 196, 1852 (1960).

2. S. I. Stepanov and E. B. Kachina-Pullo, J. Appl. Chem. (Russ), 35, 1852 (1962).

3. S. I. Stepanov and E. B. Kachina-Pullo, J. Appl. Chem. (Russ), 37, 379 (1964).

4. V. P. Kochergin, O. A. Putina, V. N. Devyatkin and E. T. Kanaeva, Protection of Metals, 11, 214 (1975).

5. I. N. Ozeryananya, N. A. Krasil'nikova, S. M. Perin, M. V. Smirnov and N. D. Shamanova, Protection of Metals, 14, 261 (1978).

6. D. O. Raleigh, J. T. White and C. A Ogden, J. Electrochem. Soc., 12, 1093 (1979).

7. H. Atmani and J. J. Rameau, Corros. Sci., 24, 279 (1984).

8. I. V. Oryshich, Met. Sci. and Heat Treat., 27, 218 (1985).

9. I. V. Oryshich and O. S. Kostyrko, Met. Sci. and Heat Treat., 27, 740 (1985). 
10. H. Atmani and J. J. Rameau, Mater. Sci. Eng., 88, 247 (1987).

11. H. Atmani and J. J. Rameau, Corros. Sci,. 27, 35 (1987).

12. O. P. Penyagina, S. M. Perin, T. I. Manukhina and N. D. Shamanova, Rasplavy (Melts), Iss. 3, 70 (1994).

13. N. D. Shamanova, I. N. Ozeryannaya and V. G. Zyryanov, Protection of Metals, 33, 276 (1997).

14. N. D. Shamanova and N. O. Esina, Protection of Metals, 35, 43 (1999).

15. H. A. Abd El-Raman, A. Baraka and S. A. Abd El-Gwad, J. Appl. Electrochem., 29, 1205 (1999).

16. C. L. Zeng, W. Wang and W. T. Wu, Corros. Sci., 43, 787 (2001).

17. E. Yanase, K. Arai, I. Watanabe, M. Takahashic and Y. Daked, J. Synchrotron Rad., 8, 490 (2001).

18. Y. S. Li, Y. Niu and W. T. Wu, Mat. Sci. and Engin., A345, 64(2003).

19. B. P. Mohanty and D. A. Shores, Corros. Sci,. 46, 2909 (2004).

20. Y. S. Lia, M. Spiegela and S. Shimadab, Mat. Chem. and Phys., 93, 217 (2005).

21. W. M. Lu, T. J. Pan, K. Zhang and Y. Niu, Corros. Sci. 50, 1900 (2008).

22. A. P. Shlyamnev, T. V. Svistunova, O. B. Lapshina, N. A. Sorokina, V. I. Motorin, V. I. Stolyarov, S. D. Bogolyubsky, N. N. Kozlova and A. F. Ederal, Corrosion Resistive, Heatproof and High Strength Steels and Alloys, pp. 43, 82, 85, 328, Intermet Engineering, Moscow (2001) (in Russian).

23. A. N. Baraboshkin, Electrocrystallization of Metals From Molten Salts, p. 58, Nauka, Moscow (1976) (in Russian).

24. H. Wiegand and M. Doruk: Arch. Elsenhuttenw., 8, 559 (1962).

25. B. Weiss and R. Stickler, Metall. Trans., 3, 851 (1972).

26. T.M. Devine: J. Electrochemical Soc., 126, 374 (1979).

27. J.K.L. Lai, Mater. Sci. Eng., 58, 195 (1983).

28. T. Sourmail, Mater. Sci. Technol., 17, 1 (2001). 